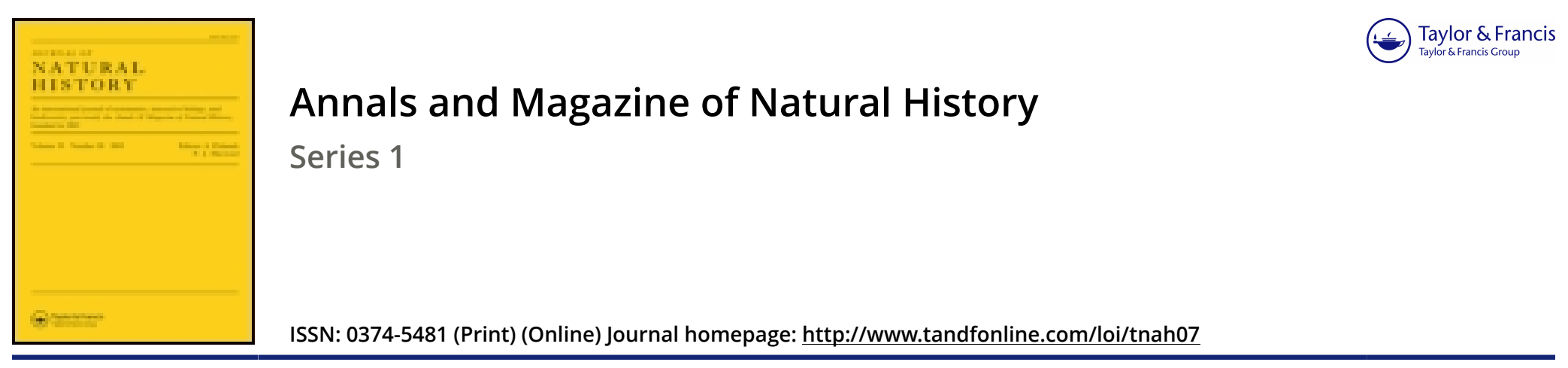

\title{
XXIV.-Description of a new British species of Callithamnion
}

\section{W.H. Harvey Esq.}

To cite this article: W.H. Harvey Esq. (1844) XXIV.-Description of a new British species of Callithamnion, Annals and Magazine of Natural History, 14:90, 186-187, DOI:

10.1080/037454809496378

To link to this article: http://dx.doi.org/10.1080/037454809496378

册 Published online: 21 Dec 2009.

Submit your article to this journal $\sqsubset \pi$

Q View related articles $₫$ 
$186 \mathrm{Mr}$.W. H. Harvey on a new British species of Callithamnion.

XXIV.-Description of a new British species of Callithamnion. By W. H. Harvey, Esq., Trinity College, Dublin.

\section{[With a Plate.]}

IN the year $1840 \mathrm{I}$ received from the Rev. J. H. Pollexfen a Callithamnion gathered by him in the Orkney Islands so distinctly characterized, that I had little difficulty in ascertaining it to be new ; and, as a just tribute to its excellent discoverer, I named it C. Pollexfenii. 'The MSS. of my 'Manual of British Algæ' had at that time left my hands, but I forwarded a description of the new Callithamnion for insertion in its proper place. By some mischance the slip was mislaid and the book published without any notice having been taken of it ; but under the MS. name of C. Pollexfenii this beautiful plant has since been known to my friends Mrs. Griffiths, Mr. Ralfs and others, and I only delayed describing it till I should have an opportunity of revising the whole of the British Callithamnia, a labour which has become necessary from the many varieties of acknowledged species which have come to my knowledge since the publication of the 'Manual,' and some of which may perhaps be admitted eventually to the rank of species.

Having lately, however, received a specimen from Dr. Dickie of Aberdeen, which exactly agrees with Mr. Pollexfen's, I no longer delay giving a description of it, as follows :-

Callithamnion Pollexfenii, Harv. Slender, flaccid, alternately much branched ; branches linear, articulate, each joint having two opposite, subulate, slender, short, spine-like, simple ramuli.

On rocks in the sea. Orkney Islands, Rev.J.H. Pollexfen, 1840; Aberdeen, Dr. Dickie, 1844, April.

Filaments $1-2$ inches high, tufted, very slender and flaccid, repeatedly branched in an alternate manner, the major divisions of the frond having a conical or spiry outline. Main stem undivided, one-tubed, jointed and transparent, having several alternate, erecto-patent, rather distant branches, which are again twice, thrice or four times branched in a similar manner, each succeeding series of branches being shorter than the preceding. Every articulation, both of the stem, the branches and the lesser divisions, emits, at a short distance below the joint or diaphragm, a pair of erecto-patent, simple, subulate, short ramuli of much less diameter than the joint from which they spring. Articulations of the branches 4-8 times, of the ramuli once and a half, or twice as long as broad. Colour a fine rosy red. Substance very tender. Fruit unknown. It closely adheres to paper in drying.

At first sight no species appears more isolated, and yet a slight inspection will show that it is closely related to $C$. cruciatum, next 
to which it may naturally be placed. It differs in being much more branched, in its spiry habit and delicate substance, and, more definitely, in having the opposite ramuli very much shorter and invariably simple and subulate. In the other British species with opposite simple ramuli (C. Turneri, Pluma and barbatum) the ramuli do not issue from every joint of the frond, nor do they spring from a point below that of the diaphragm. These characters are peculiar to $C$. Plumula (a species so different from that under consideration that I need not compare it), to C. cruciatum and C. Pollexfenii. And in another remarkable peculiarity these latter species also agree, namely, that the ramification proceeds on a plan different from that of the ramulification. In most Algæ with decompound fronds, the normal division of the branches is likewise that of the ramuli. In these it is the reverse, the branches being invariably alternate or scattered, and the ramuli as invariably opposite. Here too we never find the ramuli lengthening into branches, and they are nearly of the same size on every part of the frond. And so constantly are they produced by every articulation, that even when a branch is given off, the ramuli of the joint from whose apex it springs are as fully developed as those of any simple joint. The ramuli in these species have therefore more affinity with true leaves than with young branches.

W. H. H.

July 16,1844 .

\section{EXPLANATION OF PLATE V.}

Fig. 5. Cal. Pollexfenii, nat. size.

Fig. 6. Portion of a branch, magnified.

Fig. 7. Joints of the stem, to show the insertion of the ramuli, magnified.

XXV.-On the British Desmidieæ. By John RaLfs, Esq., M.R.C.S., Penzance*.

[With a Plate.]

Euastrum, $E h r$.

Frond simple, compressed, deeply divided into two segments which are emarginate at their ends, lobed or sinuated and generally pyramidal.

The fronds are simple, longer than broad, often oblong, compressed, and so deeply constricted that their segments seem only united by a narrow chord. The generally pyramidal segments are broadest at their bases, and are there in such close apposition for their entire breadth as nearly to conceal the notch on each side until the endochrome has collapsed. They are attenuated towards the ends, which in the adult state are always more or less

* Read before the Botanical Society of Edinburgh, April 11, 1844. 


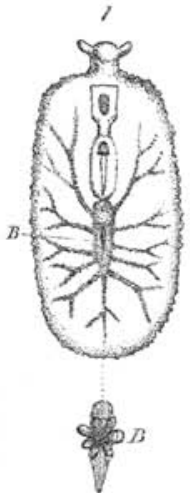

7. Planaria oceanien.

2.

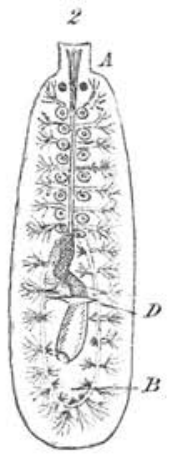

merecrostimen.

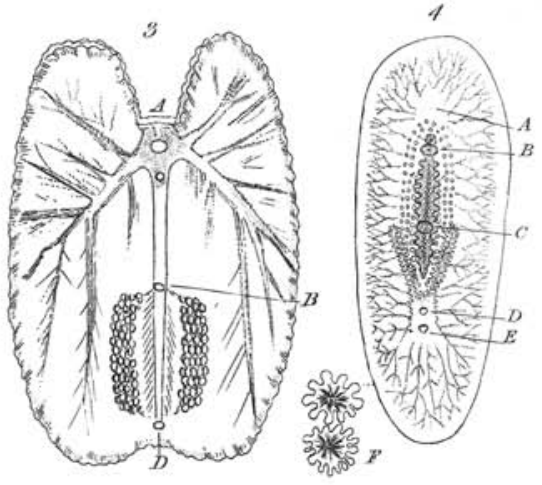

3.Planaria incisa.

1. Diplanaria notabilis.

\section{CDarwin del:}
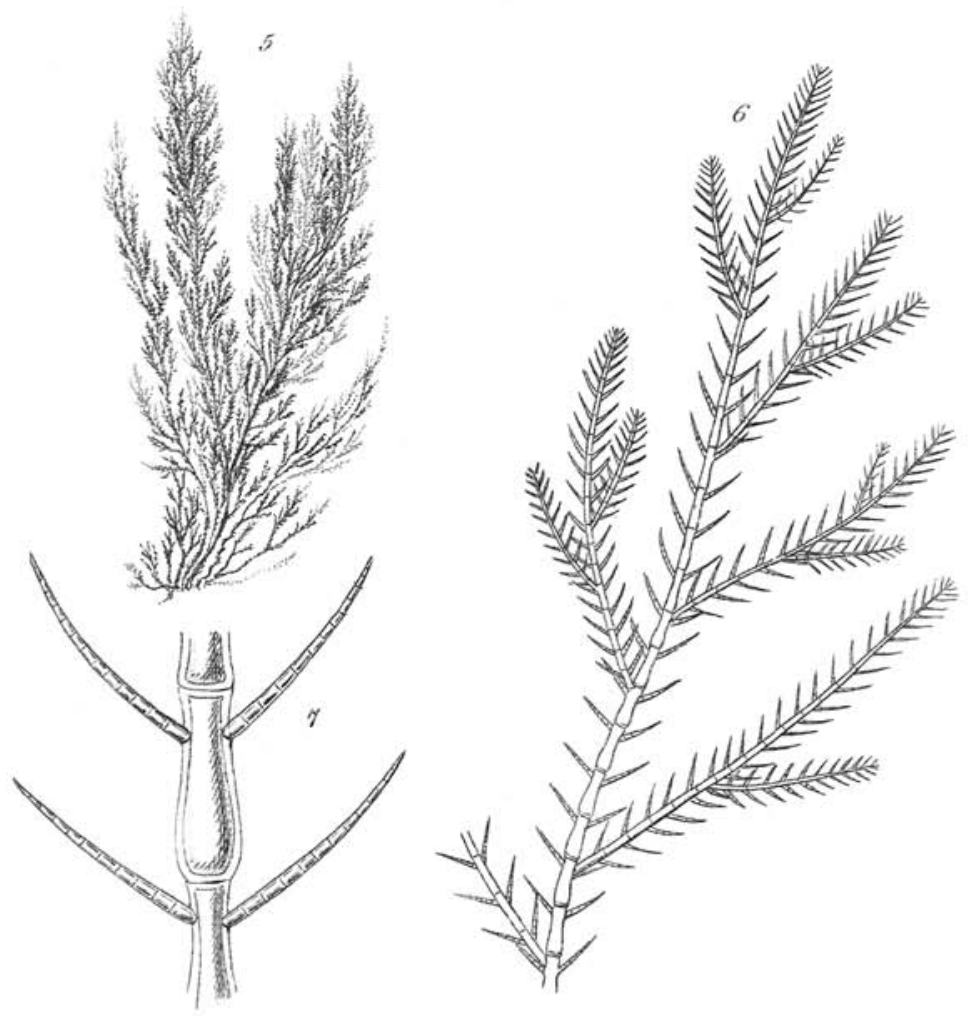

Callithammion Pollextomit. 